\title{
OBSERVATIONS OF ALBINISM IN BIRDS
}

JEAN BANCROFT, 306-200 Tuxedo Boulevard, Winnipeg, Manitoba. R3P 0R3

During the winter of 1989-90, Mr. and Mrs. Emest Taylor of East Kildonan, Winnipeg, observed at their feeder on many occasions a House Sparrow with standard plumage except for a long white stripe on the lower wings on both sides. On 11 June 1990, the Taylors saw this particular sparrow feeding a fledged white sparrow in their backyard (see photo). ${ }^{15}$ From time to time albinism and melanistic mammals and birds make an appearance.

On 26 February 1986, I observed a white House Sparrow in a flock of wild birds which were being fed by visitors at the Honolulu Zoo Park in Hawaii. ${ }^{1}$

Herbert Copland reports that the Manitoba Museum of Man and Nature has in its collection a completely white specimen of an immature House Sparrow donated by the Delta Waterfowl Research Station. This bird was collected and prepared by T. Ward in July 1941 at Delta, Manitoba, and numbered 1.2-4650. ${ }^{16}$ The museum also has "two somewhat indistinct colour photographs" of a partial albino House Sparrow taken by Michael J. Nagonchy just prior to 13 August 1986 in the north end of Winnipeg. ${ }^{10}$ A fledgling partial albino House Sparrow was found dead 31 May 1990 by Herbert Copland on a sidewalk near his home in Elmwood, Winnipeg. "This bird had large white areas on primaries and secondaries, with brown tips to these feathers on both wings and also whitish on some of the inner tail feather vanes.",

Other species of albino birds are reported. Peter Dunn of New Gretna, New Jersey, reported that in the summer of 1990 he had an albino Purple Martin hatch in one of his martin houses. ${ }^{4}$

Robert Nero makes mention of a white Great Grey Owl having been photographed near Norway House, Manitoba. ${ }^{11}$ George Holland reports having seen an albino Great Grey Owl near Patricia Beach, Manitoba. $^{6}$

W.J. Maher did a search of publications in Blue Jay and came up with a list of 29 records of albino or partially albino birds of 18 species, including records of four House Sparrows. ${ }^{8}$

Since Maher's publication there have

Table 1

Species

No. of Records

Reference

Yellow-headed Blackbird

Kestrel

Flicker (common)

American Widgeon

Great Grey Owl

Sandhill Crane

House Sparrow 


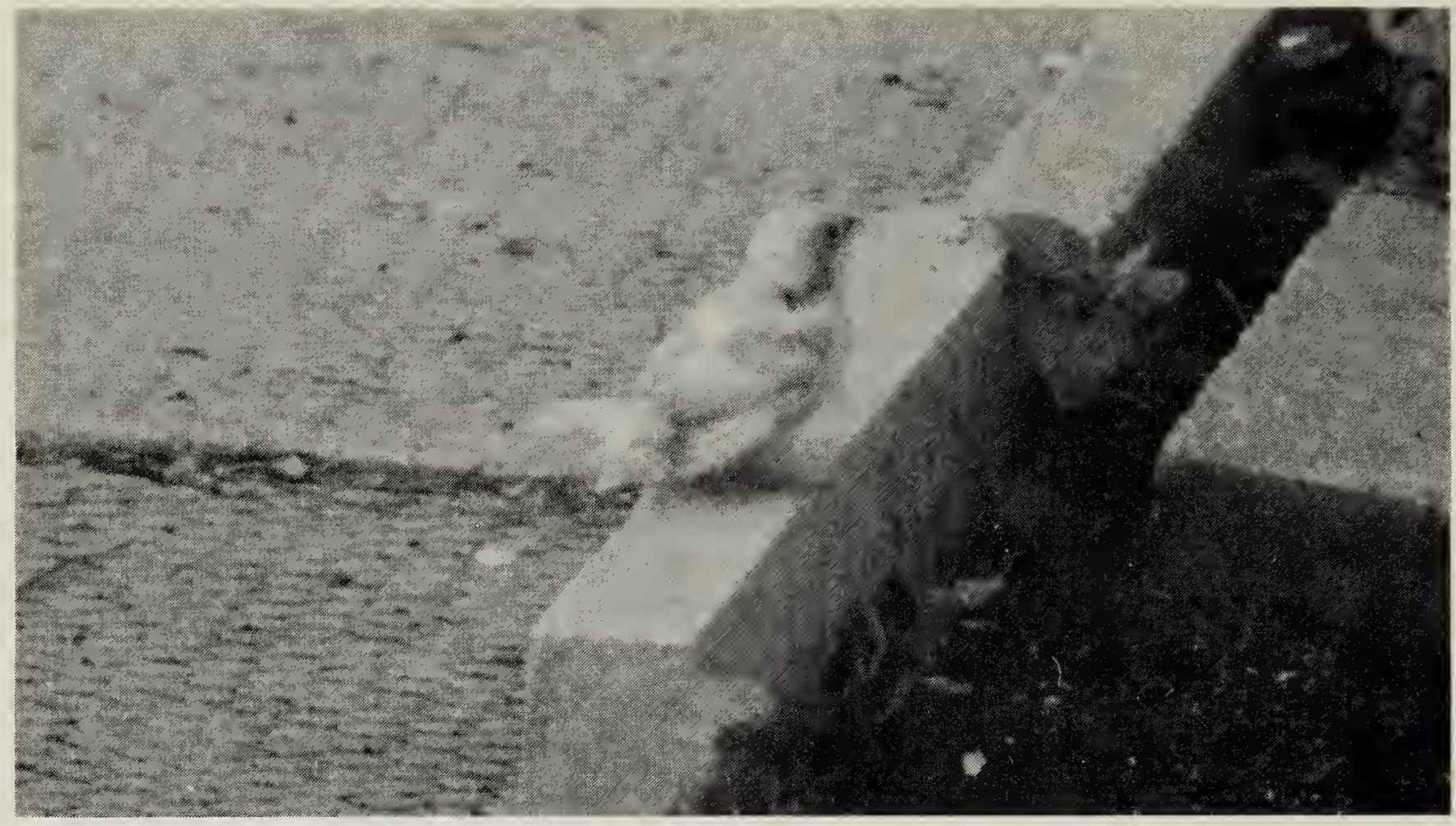

been seven additional reports of albino birds in Blue Jay (Table 1), including this article.

R.W. Nero did considerable research on plumage aberration in redwings. ${ }^{12}$ These characteristics were found in over 300 redwings. "Ninety aberrant specimens of both sexes were obtained on request from 28 museums... Practically all of the 219 adult males collected near Madison, Wisconsin, in 1952 were found to show some deviation from the wholly black plumage."12

It would appear that plumage aberrations, mostly in reduced pigmentation, occur more frequently than is generally realized.

I wish to thank R. W. Nero for his constructive criticism of an earlier draft of this article. I also thank H. W. Copland who provided access to the files of the Manitoba Ornithological Records Committee.

1. BANCROFT, J. 1986. A white House Sparrow at the Honolulu Zoo. 'Elepaio 47(8).

2. BRUNTON, D.F. and H.L. DICKSON. 1979. Adult albino Yellow-headed Blackbird in Manitoba near Virden. Blue Jay 37:112.

3. COPLAND, H.W.R. 1990. Manitoba Omith. Records Comm., Pers. comm.
4. DUNN, P.J. 1991. Albino martin baby didn't make it. Nature Society News, April 1991 , p. 2.

5. FORSYTH, A. 1988. Sightings of albino flicker at Pike Lake, Saskatchewan. Blue Jay 46:40-41.

6. HOLLAND, G. 1991. Second albino Great Grey Owl sighted in Manitoba. Blue Jay 49:32.

7. JENKINS, J. 1979. White kestrel at Eastend, Saskatchewan. Blue Jay 37:227.

8. MAHER, W.J. 1974. An albino Bam Swallow and two albino House Sparrows. Blue Jay 32:41-43.

9. MARESCHAL, M. 1973. Whiteness in an American Widgeon, Waskesiu, Saskatchewan. Blue Jay 31:232-233.

10.NAGONCHY, M.J. 1986. Manitoba Ornith. Records Comm., Pers. comm.

11.NERO, R.W. 1991. White Great Grey Owl. Blue Jay 49:31.

12. NERO, R.W. 1954. Plumage aberrations of the redwing. Auk 71:137-155.

13. SCRIVEN, R. 1984. A note on albinism in the Great Grey Owl. Blue Jay 42:173-174.

14. SHADICK, S. 1985. Albino Sandhill Crane. Blue Jay 43:137.

15. TAYLOR, E. and L. 1990. Pers. comm.

16. WARD, T. 1941. Manitoba Omith. Records Cormm., Pers. comm. 